Ambiente \& Água - An Interdisciplinary Journal of Applied Science
ISSN 1980-993X - doi:10.4136/1980-993X
www.ambi-agua.net
E-mail: ambi-agua@agro.unitau.br

\title{
Sweet almond (Prunus amygdalus "dulcis") seeds as a potential feedstock for Nigerian Biodiesel Automotive Project
}

\author{
doi: 10.4136/ambi-agua.1272 \\ Received: 03 Jan. 2014; Accepted: 10 Mar 2014 \\ Solomon Giwa $^{1 *}$; Clement Ogunbona ${ }^{2}$ \\ ${ }^{1}$ Olabisi Onabanjo University, College of Engineering and Environmental Studies - Ifo, Ogun State, Nigeria \\ Department of Agricultural and Mechanical Engineering, Ibogun Campus \\ ${ }^{2}$ Bells University of Technology, College of Natural Sciences - Ota, Ogun State, Nigeria \\ Chemical Science Laboratory \\ *Corresponding author: e-mail: sologiwa2002@yahoo.com, \\ ibido2001@yahoo.com
}

\begin{abstract}
This work presents sweet almond (Prunus amygdalus "dulcis") seed oil (SASO) as a non-conventional feedstock for the preparation of biodiesel in Nigeria, rather than the traditional oils of palm, groundnut and palm kernel. SASO was extracted via the solvent method, pretreated to reduce the acid value, and transesterified using methanol (solvent) and sodium hydroxide (catalyst). The oil content and acid value of SASO were $51.45 \pm 3.92 \%$ and $1.07 \mathrm{mg} \mathrm{KOH} / \mathrm{g}$, respectively. The fatty acid composition of SASO reveals the predominance of oleic acid (69.7\%), linoleic acid (18.2\%) and palmitic acid (9.3\%). Specific fuel properties of sweet almond oil methyl esters (SAOME) were determined using standard test methods and were found to satisfy both EN 14214 and ASTM D6751 biodiesel standards; the cold flow properties were particularly outstanding (cloud point; $-3^{\circ} \mathrm{C}$ and pour point; $-9^{\circ} \mathrm{C}$ ). SASO appears to offer great promise as a potential feedstock for biodiesel production in Nigeria.
\end{abstract}

Keywords: sweet almond seeds, fuel properties, transesterification, oil, biodiesel, Nigeria.

\section{Sementes de amêndoa doce (Prunus amygdalus "dulcis") como uma matéria-prima potencial para o Projeto Nigeriano de Biodiesel Automotive}

\section{RESUMO}

Este trabalho apresenta o óleo de semente (SASO) de amêndoa doce (Prunus Amygdalus "dulcis") como matéria-prima não convencional para a preparação de biodiesel na Nigéria em adição aos óleos tradicionais de amendoim e dendê. O SASO foi extraído usando o método de solvente, pré-tratado para reduzir o índice de acidez e transesterificado usando metanol (solvente) e hidróxido de sódio (catalisador). O teor de óleo e o valor ácido do SASO foram $51,45 \pm 3,92 \%$ e $1,07 \mathrm{mg}$ de $\mathrm{KOH} / \mathrm{g}$, respectivamente. A composição de ácidos graxos do SASO revela a predominância de ácido oleico $(69,7 \%)$, ácido linoleico $(18,2 \%)$ e ácido palmítico $(9,3 \%)$. As propriedades combustíveis específicas de ésteres metílicos do óleo de amêndoa doce (SAOME) foram determinadas utilizando métodos de ensaio normalizados e satisfizeram tanto as normas de biodiesel EN 14214 e ASTM D6751, especialmente as 
propriedades de fluxo a frio foram excelentes (ponto de nuvem; $-3^{\circ} \mathrm{C}$ e ponto de fluidez; $-9^{\circ} \mathrm{C}$ ). Conclusivamente, o SASO parece ser uma matéria-prima potencial para produção de biodiesel na Nigéria.

Palavra-chave: sementes de amêndoa doce, propriedades de combustível, transesterificação, petróleo, biodiesel, Nigéria.

\section{INTRODUCTION}

The continual use of fossil fuel has negatively impacted our society, leading to numerous global environmental problems such as the greenhouse effect, global climate change, acidification and ozone depletion. These impacts are caused by rising $\mathrm{CO}_{2}$ levels and other products of fossil fuel combustion (Ishola et al., 2013). They have affected rainfall patterns resulting in excessive rainfall and drought. Biomass-derived fuel (biofuel) has emerged as the only liquid fuel that can be substituted for fossil liquid fuels. Through biomass, fossil fuels (gasoline, diesel and liquefied petroleum gas) have been successfully partially replaced by biofuels (bioethanol, biodiesel and biogas).

Energy security is one of the main reasons why most countries engage in biofuel programs. Nigeria, a major petroleum producing and exporting nation is also embarking on biofuel projects in order to join the league of nations in benefitting from the advantages gained by the use of biofuels (Ishola et al., 2013). These projects involve the blending of up to $10 \%$ bioethanol with gasoline to achieve an E10 blend and a $20 \%$ blend of biodiesel with petro-diesel to make a B20 blend (Ishola et al., 2013). Nigeria desires to use the petroleum sector to improve the agriculture sector by investing in biofuels.

Biodiesel is a type of biofuel which can be used as a substitute for fossil-derived diesel. The use of conventional oils such as palm oil, sunflower oil, rape seed oil and soybean oil for biodiesel production is prevalent (Balat and Balat, 2008; Demirbas, 2007) and this has often strained food uses, price, production and availability of these oils (Rashid et al., 2008). This has spurred researchers to make use of inedible oils, waste cooking oils and lesser known oils in the production of biodiesel (Balat and Balat, 2008; Ofoefule et al., 2013; Bamgboye and Oniya, 2012).

Oils of some oil-bearing plants have been investigated as potential feedstocks for biodiesel production in Nigeria. These include; palm oil (Izah and Ohimain, 2013), palm kernel oil (Alamu et al., 2008), egusi melon oil (Giwa, et al., 2010), coconut oil (Alamu et al. 2010), tigernut (Ofoefule et al., 2013), African mango nut oil (Bello et al., 2011) and Moringa oleifera (Aliyu et al., 2013). Of all the oil-bearing crops prevalent in the country, palm kernel, groundnut and oil palm are the most abundant and this informed their selection as the preferred feedstocks for biodiesel production in the country's biofuel projects (Ishola et al., 2013). However, this is accomplished at the expense of the food use of these traditional oils.

Almond seeds are included in the family Rosaceae in addition to Pomoideae (apples, pears), Prunoideae (apricot, cherry, peach, and plum) and Rosoideae (blackberry, strawberry) fruits. There are two major varieties of almonds, the bitter almond (Prunus amygdalus "amara") and the sweet almond (Prunus amygdalus "dulcis") used mainly for culinary purposes, and making of oils and flavourings, respectively (Agunbiade and Olanlokun, 2006). Almond (Prunus amygdalus "dulcis") is one of the species of Prunus belonging to the subfamily Prunoideae of the family Rosaceae. Almond seeds contain approximately 51\% lipid, $21 \%$ protein, $20 \%$ carbohydrate and $12 \%$ fiber.

Harnessing the inexpensive and neglected sweet almond seed as raw material for biodiesel production in Nigeria is an effective way to reduce the food-fuel strain on the use of traditional oils (palm oil, groundnut oil and palm kernel oil). The primary aim of the work is 
to investigate the possible use of sweet almond (Prunus amygdalus "dulcis") seed oil as an alternative feedstock for the production of biodiesel in Nigeria.

\section{MATERIALS AND METHODS}

\subsection{Materials}

Fully matured sweet almond fruits (Prunus amygdalus "dulcis") were collected fresh in April, 2012, in front of the Administration building of the College of Engineering and Environmental Studies of Olabisi Onabanjo University, Ifo, Ogun State, Nigeria. The edible portion (flesh) was manually removed, leaving the stony shell containing the seed. The stony shell was carefully cracked to remove the groundnut-like seed. $2 \mathrm{~kg}$ of almond seeds were gathered and sun-dried for two weeks before being milled using a domestic blender. The resulting powder was preserved in polypropylene bags under cool conditions in preparation for oil extraction. The seeds and fruits of sweet almond are shown in Figure 1. Pure fatty acid methyl esters were purchased from Sigma Chemical Co. (USA). The chemicals (analytical grade) supplied from Merck, Germany were: methanol of $99.5 \%$ purity, sodium hydroxide pellets of $85 \%$ purity, sodium sulfate powder of $98 \%$ purity and n-hexane of $99 \%$ purity.

\subsection{Oil extraction}

The lipid components of the milled sweet almond seeds (1000 g) were subsequently extracted with n-hexane using a Soxhlet apparatus at $45-50{ }^{\circ} \mathrm{C}$ for $6-8 \mathrm{~h}$ until the extraction was completed. The solvent was removed from the oil using rotary vacuum evaporator at $65^{\circ} \mathrm{C}$ under reduced pressure. Oil content was calculated from the weight difference of the dried seeds sample before and after extraction. After the extraction process, the oil obtained was stored in a cool dry place pending analysis. The acid value of sweet almond seed oil was measured by the AOCS Official Method Cd 3d-63. The oil content and acid value determinations were performed in triplicate, and the data reported as mean \pm standard deviation.

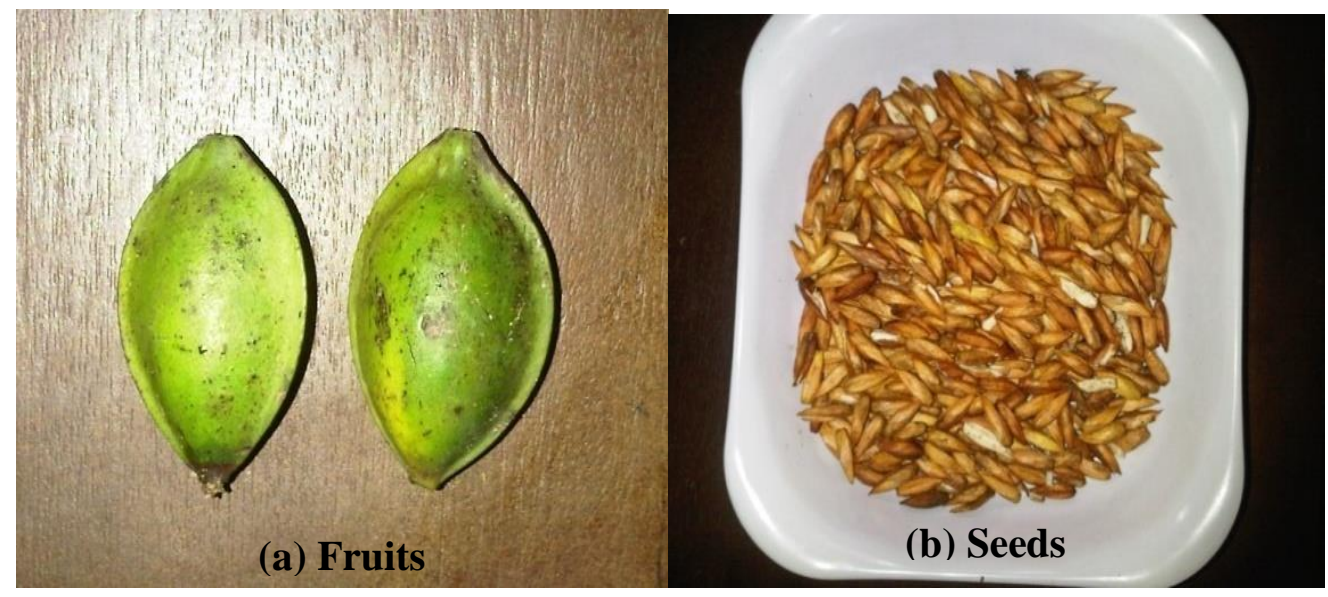

Figure 1. Fruits and seeds of sweet almond.

\subsection{Pretreatment of oil}

Due to the slightly high free fatty acid (FFA) of the sweet almond seed oil (4.90\%) soap formation may occur during the transesterification reaction when alkaline catalyst is used and this will affect the esters yield. Moreover, in the catalytic transesterification, FFA and water always produce negative effects, consuming the catalyst and reducing the catalyst's effectiveness. The oil was pretreated with potassium hydroxide to reduce the FFA to $0.76 \%$. 


\subsection{Transesterification reaction}

The transesterification reaction was carried out in a $2 \mathrm{~L}$ three-necked round bottom reactor equipped with reflux condenser, heater (with magnetic stirrer) and a thermometer. $500 \mathrm{~g}$ of sweet almond seed oil (SASO) was put into the reactor and heated to a temperature of $60{ }^{\circ} \mathrm{C}$. An appropriate amount of methanol $(109.65 \mathrm{~g})$ was poured in a beaker with the required quantity of $\mathrm{NaOH}(5 \mathrm{~g} ; 1 \% \mathrm{w} / \mathrm{w}$ with respect to oil) pellet added to it. The content of the beaker was manually stirred vigorously until the $\mathrm{NaOH}$ was completely dissolved in the methanol to give a mixture (sodium methoxide). The sodium methoxide was poured into the reactor containing the heated oil and the entire content in the reactor was stirred at the rate of $600 \mathrm{rpm}$ (using magnetic stirrer) and the temperature maintained at $60 \pm 1{ }^{\circ} \mathrm{C}$. This marked the commencement of the reaction that was allowed for $1 \mathrm{~h}$, after which the heating and stirring was stopped. The product of the reaction was allowed to cool to room temperature and then poured into a separating funnel to settle down overnight. It was observed that the reaction product had settled into two distinct layers of glycerol (lower) and crude sweet almond oil methyl esters (upper). The crude sweet almond oil methyl esters (SAOME) was collected separately from the separating funnel and heated on a rotary vacuum evaporator under reduced pressure at $80^{\circ} \mathrm{C}$ until the excess methanol was completely removed. Thereafter, the crude SAOME was gently washed (three times) with warm distilled water to remove residual catalyst or soaps. It was then dried with anhydrous sodium sulphate and filtered, and the resulting product (purified SAOME) stored in a cool dry place prior to further analysis. The procedure was repeated in triplicate and the average yield reported.

\subsection{Methyl ester analysis and biodiesel yield}

The fatty acid (FA) composition of SAOME was analyzed by an Agilent gas chromatograph (GC), model 7890A, coupled with flame ionization detector (FID). This was carried out according to the EN 14103 standard method. Separation was done with a DB-WAX capillary column (30 m x $0.25 \mathrm{~mm}$, I.D x $0.25 \mu \mathrm{m}, 1.0 \mu \mathrm{l}$ and $0.10 \mu \mathrm{m}$; J \& W Scientific, Folsom, CA, USA). Helium was used as the carrier gas. Oven temperature was held at $210^{\circ} \mathrm{C}$ for $9 \mathrm{~min}$ and then increased to $230^{\circ} \mathrm{C}$ (held $10 \mathrm{~min}$ ) at a rate of $20^{\circ} \mathrm{C} / \mathrm{min}$. Injector and detector were set at $250{ }^{\circ} \mathrm{C}$ and $300^{\circ} \mathrm{C}$, respectively. A sample volume of $1.0 \mu \mathrm{L}$ was injected using split mode (split ratio of 1:50). Fatty acid methyl esters were identified by comparing their relative and absolute retention times with those of authentic standards. Quantification was done by Chem Station data handling software incorporated in the GC. The free and total glycerol present in the AOME was analyzed using GC in accordance with ASTM D6584 standard method. The same GC used above was equipped with a capillary column of DB-5HT $(15 \mathrm{~m} \times 0.25 \mathrm{~mm}$, I.D x $0.25 \mu \mathrm{m}, 1.0 \mu \mathrm{l}$ and $0.10 \mu \mathrm{m}$; J \& W Scientific, Folsom, CA, USA).

For the present work, the biodiesel yield was determined using the following Equation 1.

$$
\text { Yield }(\%)=\frac{\text { weight of methyl ester produced }}{\text { weight of oil used in reaction }} \times 100
$$

\subsection{Fuel properties determination}

Biodiesel fuel properties of AOME were determined using standard test methods. The following fuel properties were measured: acid value (ASTM D664), kinematic viscosity (ASTM D4052), cold flow plugging point (ASTM D6371), iodine value (EN 14111), cloud point (ASTM D2500), oxidative stability (EN 14112) and flash point (ASTM D93). The cetane number $(\mathrm{CN})$ of the biodiesel was determined empirically (Ramos et al., 2009). 


\section{RESULTS AND DISCUSSION}

\subsection{Oil content, acid value and biodiesel yield}

Oil content is a key factor influencing the overall choice of sweet almond seed (SAS) as potential feedstock for biodiesel production. SASs was found to contain after extraction $51.45 \pm 3.92 \%(\mathrm{w} / \mathrm{w})$ oil. The oil content of SASs is similar to those of Siberian apricot $(51.15 \pm 7.12 \%)$, Moringa oleifera (51\%), palm kernel $(50 \%)$ and egusi melon $(51 \%)$, and much higher than those of soybean (17\%), cotton (15\%) and tigernut (Cyperus esculentus) (16\%) (Wang 2013; Ishola et al., 2013; Aliyu et al., 2013; Ofoefule et al., 2013; Pinto et al., 2005). The acid value of sweet almond seed oil (SASO) was determined to be $0.38 \mathrm{mg}$ $\mathrm{KOH} / \mathrm{g}$ after pretreating the oil because the initial acid value $(2.45 \mathrm{mg} \mathrm{KOH} / \mathrm{g})$ was slightly higher than the value $(\leq 2 \mathrm{mg} \mathrm{KOH} / \mathrm{g})$ recommended for direct base-catalyzed transesterification. Biodiesel yield of SASO was obtained at $85.9 \%$.

\subsection{Fatty acid profile}

The FA composition in the SASO analyzed was identified as palmitic acid (C16:0; 9.3\%), palmitoleic acid (C16:1; 0.3\%), stearic acid (C18:0; 1.8\%), oleic acid (C18:1; 69.7\%), linoleic acid $(\mathrm{C} 18: 2 ; 18.2 \%)$ and linolenic acid $(\mathrm{C} 18: 3,0.7 \%)$ (Table 1$)$. The percentage of FA composition obtained in this study was closely similar to those of other species of almond previously reported (Chu et al., 2013; Wang, 2013), with the exception of Iranian almond (Atapour and Kariminia, 2011). Also, the FA profile of SASO is close to that of canola oil (Moser and Vaughn, 2010). Of the six FAs, oleic acid was the most prevalent, accounting for $69.7 \%$, and palmitic acid $(9.3 \%)$ was the predominant saturated FA. The total saturated and unsaturated FA contents of the oil are $11.1 \%$ and $88.9 \%$, respectively. Oils with high percentages of monounsaturated FA are ideal biodiesel raw materials (Ramos et al., 2009; Knothe, 2008). Consequently, with 70.0\% monounsaturated FA content, SASO represents a good feedstock for biodiesel production. Because transesterification reaction does not alter FA composition of the oil (SASO), the FA composition of SAOME was not determined (Ramos et al., 2009).

Table 1. Physico-chemical properties and fatty acid compositions of SASO.

\begin{tabular}{l|c}
\hline \multicolumn{1}{c|}{ Property } & Sweet almond seed oil \\
\hline Oil content (wt.\%) & $51.45 \pm 3.92^{\mathrm{a}}$ \\
Acid value (mg KOH/g) & $2.45(0.38)^{\mathrm{b}}$ \\
Free fatty acid (\%) & $4.9(0.76)^{\mathrm{b}}$ \\
\hline \multicolumn{2}{|c}{ Fatty acid composition (wt.\%) } \\
\hline Palmitic (C16:0) & 9.3 \\
Palmitoleic (C16:1) & 0.3 \\
Stearic (C18:0) & 1.8 \\
Oleic (C18:1) & 69.7 \\
Linoleic (C18:2) & 18.2 \\
Linolenic (C18:3) & 0.7 \\
Total saturated acids (Cn:0) & 11.1 \\
Total monounsaturated acids (Cn:1) & 70.0 \\
Total polyunsaturated acids (Cn:2,3) & 18.9 \\
Total unsaturated acids & 88.9 \\
Molecular weight (g/mol) & 874.5 \\
\hline
\end{tabular}

${ }^{\mathrm{a}}$ Values are mean \pm standard deviation of triplicate determination; ${ }^{\mathrm{b}}$ values obtained after the oil pretreatment. 


\subsection{Fuel properties}

\subsubsection{Kinematic viscosity}

Viscosity is a measure of a fuel's flow characteristics and its tendency to deform under stress. Kinematic viscosity (KV) is an important parameter with regard to fuel atomization as well as fuel distribution. The KV of biodiesel is significantly influenced by the feedstock used. The KV of sweet almond oil biodiesel at $40{ }^{\circ} \mathrm{C}$ was determined to be $4.23 \mathrm{~mm}^{2} / \mathrm{s}$, which is within the ranges specified by ASTM D6751 and EN 14214 (Table 2). Since SAOME contained a large amount of unsaturated FAs $(88.9 \%)$ and a considerable percentage of monounsaturated FAs $(70.0 \%)$, it exhibited a slightly high KV.

\subsubsection{Oxidative stability}

Oxidative stability (OS) is an important technical issue affecting biodiesel quality (Knothe, 2008). A minimum Rancimat induction period of 3 and $6 \mathrm{~h}$ is defined for biodiesel fuel using ASTM D6751 and EN 14214 standards, respectively. As provided in Table 2, sweet almond biodiesel OS $(3.1 \mathrm{~h})$ was slightly higher than that recommended by ASTM D6751 $(3 \mathrm{~h})$ and lower than that specified by EN $14214(6 \mathrm{~h})$. The relatively good OS of SAOME may be attributed to the slightly low percentage of methyl linoleate (18.2\%), which has an OS of $0.94 \mathrm{~h}$ (Knothe, 2008). Addition of antioxidants can help improve the OS of SAOME (Chu et al., 2013), but will increase the cost of the biodiesel product. However, an inexpensive alternative solution to the problem of OS involves blending biodiesel with diesel fuel.

\subsubsection{Flash point}

Flash point (FP) of a fuel is the temperature at which it will ignite when exposed to a flame or spark. Biodiesel with a higher FP than petro-diesel possesses the benefit of higher safety for transport purposes. The biodiesel produced from SASO had a FP $\left(169{ }^{\circ} \mathrm{C}\right)$ greater than conventional diesel $\left(77^{\circ} \mathrm{C}\right.$ ) by $92{ }^{\circ} \mathrm{C}$ (Table 2$)$. This value is significantly above the minimum limits prescribed in ASTM D6751 and EN 14214 standards.

\subsubsection{Cetane number}

The cetane number $(\mathrm{CN})$ measures the tendency of the fuel to self-ignite at the temperature and pressure in the cylinder when the fuel is injected. It is one of the key parameters considered in the use of methyl esters as fuel since a satisfactory $\mathrm{CN}$ is required for good engine performance. As presented in Table 2, the calculated CN for SAOME was 58.3. This value is reasonable considering that the FA composition of SASO mainly consisted of $69.7 \%$ oleic acid and $18.2 \%$ linoleic acid, and the $\mathrm{CN}$ of pure methyl linoleate and methyl oleate are 38.2 and 59.2, respectively (Chu et al., 2013; Knothe et al., 2008). The CN determined for SAOME satisfies both ASTM D6751 and EN 14124 quality standards that set minimum limits of 47 and 51, respectively.

\subsubsection{Cold flow}

The cold flow properties of SAOME were measured by determination of cloud point (CP) and pour point (PP). CP and PP are important low-temperature fuel parameters. The CP is the temperature at which crystal growth is large enough to be visible to the naked eye while the PP is the lowest temperature at which the fluid will pour. Specifications for CP and PP are not in the biodiesel standards, although ASTM D6751 requires that CP be reported; this is because each country has different climatic conditions. As presented in Table 2, the sweet almond biodiesel has satisfactory $\mathrm{CP}$ of -3 and PP of $-9{ }^{0} \mathrm{C}$. These values are mostly good because the SASO FAs composition has a high percentage $(90.4 \%)$ of long-chain unsaturated FAs (Table 1). 
Table 2. Fuel properties of the sweet almond oil methyl ester compared with biodiesel standards.

\begin{tabular}{|c|c|c|c|c|}
\hline \multirow{2}{*}{ Property } & \multirow{2}{*}{ Unit } & \multicolumn{2}{|c|}{ Limits } & \multirow{2}{*}{ SAOME } \\
\hline & & ASTM D6751 & EN 14214 & \\
\hline Kinematic viscosity; $40^{\circ} \mathrm{C}$ & $\mathrm{mm}^{2} / \mathrm{s}$ & $1.9-6.0$ & $3.5-5.0$ & 4.23 \\
\hline Flash point & ${ }^{\circ} \mathrm{C}$ & $130 \mathrm{~min}$ & $120 \mathrm{~min}$ & 169 \\
\hline Cloud point & ${ }^{\circ} \mathrm{C}$ & Report & $-^{*}$ & -3 \\
\hline Acid value & $\mathrm{mg} \mathrm{KOH} / \mathrm{g}$ & $0.5 \max$ & $0.50 \max$ & 0.13 \\
\hline Linolenic acid content & $\%(\mathrm{~mol} / \mathrm{mol})$ & $-{ }^{*}$ & $12.0 \max$ & 0.7 \\
\hline Oxidative stability & $\mathrm{h}$ & $3 \mathrm{~min}$ & $6 \mathrm{~min}$ & 3.1 \\
\hline Pour point & ${ }^{\circ} \mathrm{C}$ & $-{ }^{*}$ & $-{ }^{*}$ & -9 \\
\hline Cetane number & & $47 \mathrm{~min}$ & $51 \mathrm{~min}$ & $58^{\mathrm{a}}$ \\
\hline Free glycerol & mass $\%$ & $0.02 \max$ & $0.02 \max$ & 0.013 \\
\hline Total glycerol & mass $\%$ & $0.24 \max$ & $0.25 \max$ & 0.172 \\
\hline
\end{tabular}

*Not specified; ${ }^{\mathrm{a}}$ Empirically determined.

\subsubsection{Acid value}

Acid value (AV) is a measure of the FFA content in the biodiesel and is expressed as the milligram of $\mathrm{KOH}$ required to neutralize the FFAs in 1 gram of the sample. The AV of the sweet almond oil biodiesel produced in the present work was $0.21 \mathrm{mg}$ of $\mathrm{KOH} / \mathrm{g}$. The AV of sweet almond oil biodiesel satisfied this specification $(0.5 \mathrm{mg} \mathrm{KOH} / \mathrm{g})$, and is an indication of good biodiesel quality in this regard. As seen in Table 2, the AV of SAOME $(0.21 \mathrm{mg}$ $\mathrm{KOH} / \mathrm{g}$ ) conforms to ASTM D6751 and EN 14214 standards.

\subsubsection{Iodine value}

The iodine value (IV) is an index of the number of double bonds within a mixture of FA contained in biodiesel. Therefore, it is a measure of the total unsaturation of a fatty material measured in grams of iodine per $100 \mathrm{~g}$ of sample when iodine is formally added to the double bonds. The IV of sweet almond oil biodiesel was $92.3 \mathrm{~g} \mathrm{I}_{2} / 100 \mathrm{~g}$. The result satisfied the specification of $120 \mathrm{~g} \mathrm{I}_{2} / 100 \mathrm{~g}$ (maximum) recommended by EN 14214 standards, as shown in Table 2.

\subsubsection{Other fuel properties}

Other fuel properties of sweet almond oil biodiesel, such as free glycerin and total glycerin, were also determined (Table 2). Expectedly, these aforementioned properties of sweet almond oil biodiesel complied with EN 14214 and ASTM D6751 standards. Also, the linolenic acid contained in the SASO (0.7\%) is significantly lower than the $12 \%$ recommended by EN 14214 (Table 1).

\section{CONCLUSIONS}

SASs have considerable oil content (over 50\%) which underwent pre-treatment prior to direct transesterification. The conversion of SASO into methyl esters via alkaline transesterification was investigated in order to find a feedstock suitable for biodiesel production in Nigeria that is not also in demand as food. Selected fuel properties of SAOME 
were measured $\left(\mathrm{KV}=4.23 \mathrm{~mm}^{2} / \mathrm{s}, \mathrm{FP}=169^{\circ} \mathrm{C}, \mathrm{OS}=3.1 \mathrm{~h}, \mathrm{CN}=58, \mathrm{CP}=-3^{\circ} \mathrm{C}\right.$ and $\mathrm{PP}=-$ $9{ }^{\circ} \mathrm{C}$ ) and compared to the biodiesel standards (ASTM D6751 and EN 14214), and a satisfactory agreement with these standards was observed. Also, the feedstock (SASO) was analyzed to contain six FAs, of which oleic acid (69.7\%) is the most predominant. Finally, SASO seems a potential substitute for palm oil, groundnut oil and palm kernel oil, which are the predominant oils available in the country as feedstocks for biodiesel production.

\section{ACKNOWLEDGEMENTS}

We hereby acknowledge the immeasurable contributions and support of Miss Oluwaseun Akinwoye and Mrs. Tessy Oguntoyinbo of Bells University of Technology, Ota, Ogun State, Nigeria during the course of this research.

\section{REFERENCES}

AGUNBIADE, S. O.; OLANLOKUN, J. O. Evaluation of some nutritional characteristics of Indian almond (Prunus amygdalus) Nut. Pakistan J. Nutr, v. 5, p. 316-318, 2006.

ALAMU, O. J.; DEHINBO, O.; SULAIMAN, A. M. Production and testing of coconut oil biodiesel fuel and its blend. Leonardo J. Sci., v. 16, p. 95-104, 2010.

ALAMU, O. J.; WAHEED, M. A.; JEKAYINFA, S.O. Effect of ethanol-palm kernel oil ratio on alkali-catalyzed biodiesel yield, Fuel, v. 87, p. 1529-1533. 2008. http://dx.doi.org/10.1016/j.fuel.2007.08.011.

ALIYU, A. O.; NWAEDOZIE, J. M.; ADAMS, A. Quality parameters of biodiesel produced from locally sourced moringa oleifera and citrullus colocynthis 1 . Seeds found in Kaduna, Nigeria. Int. Res. J. Pure Appl. Chem., v. 3, p. 377-390, 2013.

ATAPOUR, M.; KARIMINIA, H. R. Characterization and transesterification of Iranian bitter almond oil for biodiesel production. Appl. Energy, v. 88, p. 2377-2381, 2011. http://dx.doi.org/10.1016/j.apenergy.2011.01.014

BALAT, M.; BALAT, H. A critical review of biodiesel as vehicular fuel. Energy Convers. Manag., v. 49, p. 2727-2741, 2008. http://dx.doi.org/10.1016/j.enconman.2008.03.016

BAMGBOYE, A. I.; ONIYA, O. O. Fuel properties of loofah (Luffa cylindrica L.) biofuel blended with diesel. Afr. J. Environ. Sci. Technol., v. 6, p. 346-352, 2012.

BELLO, E. I.; FADE-ALUKO, A. O.; ANJORIN, S. A.; MOGAJI, T. S. Characterization and evaluation of African bush mango Nut (Dika nut) (Irvingia gabonensis) oil biodiesel as alternative fuel for diesel engines. J. Petro. Technol. Alter. Fuels, v. 2, p. 176-180, 2011.

CHU, J. M.; XU, X. Q.; ZHANG, Y. L. Production and properties of biodiesel produced from Amygdalus pedunculata Pall. Bioresour. Technol., v. 134, p. 374-376, 2013.

DEMIRBAS, A. Importance of biodiesel as transportation fuel. Energy Policy, v. 35, p. 4661-4670, 2007. http://dx.doi.org/10.1016/j.enpol.2007.04.003

GIWA, S. O.; CHUAH, L. A.; ADAM, N. M. Investigating "Egusi"(Citrullus Colocynthis L.) Seed oil as potential biodiesel feedstock. Energies, v. 3, p. 607-618, 2010. http://dx.doi.org/10.3390/en3040607 
ISHOLA, M. M.; BRANDBERG, T.; SANNI, S. A.; TAHERZADEH, M. J. Biofuels in Nigeria: a critical and strategic evaluation. Renew. Energy, v. 55, p. 554-560, 2013. http://dx.doi.org/10.1016/j.renene.2012.12.021

IZAH, S. C.; OHIMAIN, E. I. The Challenge of Biodiesel Production from Oil Palm Feedstock in Nigeria. Greener Journal of Biological Sciences, v. 3, p. 1-12, 2013.

KNOTHE, G. "Designer" biodiesel: optimizing fatty ester composition to improve fuel properties. Energy Fuels, v. 22, p. 1358-1364, 2008. http://dx.doi.org/10.1021/ef700639e

MOSER, B. R.; VAUGHN, S. F. Evaluation of alkyl esters from Camelina sativa oil as biodiesel and as blend components in ultra low-sulfur diesel fuel. Bioresour. Technol., v. 101. p. 646-653, 2010. http://dx.doi.org/10.1016/j.biortech.2009.08.054

OFOEFUlE, A. U.; IBETO, C. N.; OKORO, U. C.; ONUKWULI, O. D. Biodiesel Production from Tigernut (Cyperus esculentus) Oil and Characterization of its Blend with Petro-diesel. Phy. Rev. Res. Int.l, v. 3, p. 145-153, 2013.

PINTO, A. C.; GUARIEIRO, L. L. N.; REZENDE, M. J. C.; RIBEIRO, N. M.; TORRES, E. A.; LOPES, W. A. et al. Biodiesel: an overview. J. Braz. Chem. Soc., v. 16, p. 13131330, 2005. http://dx.doi.org/10.1590/S0103-50532005000800003

RAMOS, M. J.; FERNANDEZ, C. M.; CASAS, A.; RODRIGUEZ, L.; PEREZ, A. Influence of fatty acid composition of raw materials on biodiesel properties. Bioresour. Technol., v. 100, p. 261-268, 2009. http://dx.doi.org/10.1016/j.biortech.2008.06.039

RASHID, U.; ANWAR, F.; MOSER, B. R.; ASHRAF, S. Production of sunflower oil methyl esters by optimized alkali-catalyzed methanolysis. Biomass Bioenergy, v. 32, p. 1202 1205, 2008. http://dx.doi.org/10.1016/j.biombioe.2008.03.001

WANG, L. Properties of Manchurian apricot (Prunus mandshurica Skv.) and Siberian apricot (Prunus sibirica L.) seed kernel oils and evaluation as biodiesel feedstocks. Ind. Crops Prod., v. 50, p. 838-843, 2013. http://dx.doi.org/10.1016/j.indcrop.2013.08.072 